\title{
Utilization of coal and waste for ecological fuel production
}

\author{
P. Sedlacek, J. Vales \& M. Safarova \\ Department of Research and Development, \\ Brown Coal Research Institute, j.s.c., Czech Republic
}

\begin{abstract}
When processing brown coal mined in the North Bohemian Basin, dusty types of low heating coal containing lots of ash are produced. This coal is difficult to sell. On the other hand when bituminous coal is produced, the waste is very fine, with a high calorific value, which is impossible to sell. World wide continuously increasing amounts of waste and their further processing is a big problem. For processing waste combined with coal the most suitable types of waste are those individual types of coal which use favourable qualities of reprocessed high-energy waste.

Keywords: brown coal, waste, desulphurization, sulphur emissions.
\end{abstract}

\section{Introduction}

Reliable and economically available energy sources are a key issue for the good economic function of any state. Therefore the basic aim of energy policies of European states is to ensure energy self-sufficiency and at the same time reduce the energy consumption of consumers.

Globally, coal is the second most-used raw energy material in the world (after crude oil). In $200226 \%$ of world energy was produced by burning coal (more than 4.74 milliard tons of coal). According to an estimation by the IEA, world demand for coal will rise by approximately $1.4 \%$ per year until. It is expected that the amount of electricity produced in coal power plants will rise by $4 \%$ per year over the same period. Coal as a fuel has a number of economic advantages. It is situated in rich deposits that are more evenly located when compared to crude oil, and even less-developed countries are able to handle its, which is not too economically demanding. 
A significant disadvantage of producing electricity from coal is the operation of ecologically-damaging combustion equipment, which generates a huge amount of pollution, including so-called greenhouse gases which cause global warming and climate change.

One possible way of using remaining relatively large coal deposits and lowering levels of air pollution are so-called Clean Coal Technologies, e.g. separation of carbon dioxide from the combustion products and depositing into underground reservoirs (e.g. closed mines) [2].

The main energy source in the Czech Republic is coal. The main areas of coal mining in the Czech Republic are in the Ostrava region and in the Ore Mountains region. In the Ostrava region there is mined coking bituminous coal in deep mines and in the opencast mines of the Ore Mountains region there is brown coal.

Burning coal, particularly brown coal, is accompanied by the production of carbon dioxide, sulphur oxides and other substances, which are emitted into the air. The issue of pollution produced by burning dusty coal, such as those used in heating and energy production industries, is remedied by the subsequent desulphurisation of combustion products or construction or reconstruction of existing combustion equipment to cope with more modern fluid technologies that meet the valid legislation regarding pollution.

Sorted coal has a higher sulphur content and when burned, pollution limits laid out in legislation are exceeded. The additive procedure, which is used mainly for dusty types of coal, was in the past verified for sorted types as well. However, efficiency was very low when burning. Suitable fuel for coal boilers with a low heat output, which burn the sorted types of coal, and which are often the biggest local producers of pollution, could become multi-component fuel made from brown coal and biomass waste as well as some combustible waste materials modified by admixtures so that burning would produce significantly less pollution, especially $\mathrm{SO}_{2}$ (compared to burning just brown coal.) The aim of this project was to verify the production possibilities of such fuel [1].

Table 1: Total annual production of brown coal in the Czech Republic in the years $2002-2004$.

\begin{tabular}{|c|c|c|c|c|c|c|}
\hline \multirow{2}{*}{$\begin{array}{l}\text { Mining } \\
\text { company }\end{array}$} & \multicolumn{2}{|l|}{2002} & \multicolumn{2}{|l|}{2003} & \multicolumn{2}{|l|}{2004} \\
\hline & $\begin{array}{l}\text { Thousands } \\
\text { of tons }\end{array}$ & $\%$ & $\begin{array}{l}\text { Thousands } \\
\text { of tons }\end{array}$ & $\%$ & $\begin{array}{l}\text { Thousands } \\
\text { of tons }\end{array}$ & $\%$ \\
\hline MU, j.c.s. & 16,6 & 33,1 & 16,9 & 32,6 & 16,6 & 33,3 \\
\hline SD, j.s.c. & 21,8 & 43,8 & 23,4 & 45,2 & 22,0 & 44,9 \\
\hline SU, j.s.c. & 11,3 & 23,1 & 11,4 & 22,2 & 10,3 & 21,8 \\
\hline Total & 49,7 & 100 & 51,7 & 100 & 48,9 & 100 \\
\hline
\end{tabular}

\section{Mining of brown coal in the Czech Republic}

In the Czech Republic there are three companies that mine coal in two areas; the North Bohemian Coal Basin and the Sokolov Coal Basin. In the Table 1 the 
overall production of brown coal in the Czech Republic and market share of the companies at the market are summarised.

\section{Components of ecological fuel}

The verification of ecological fuel production was based on the use of three components; brown coal, waste and biomass.

\subsection{Brown coal}

From the very beginning of the project, coal had been considered a major constituent of the new fuel type. The fuel should always consist of at least $30 \%$ coal. Brown coal with a high sulphur content from MU, j.s.c. was used for this purpose. The problem, which is being solved by the treatment and processing of brown coal, is using low heating dusty types of coal. The types of coal that are created during the treatment of the sorted types are mostly used for burning in large power and heating plants. Their calorific value is about $11 \mathrm{MJ}_{\mathrm{kg}}^{-1}$. Another problem is the higher sulphur content, which is one of the reasons for the limited use of these types for direct burning in boilers of small thermal performance regarding the $\mathrm{SO}_{2}$ pollution [4].

\subsection{Biomass}

Industrial crops grown for energy are called energy crops. The final products of energy crops processing are bio-fuels (phyto-fuels), which are categorised according to their states as solids (briquettes, pellets), liquids (vegetable oils, bio-diesel oil) or gases (biogas). Currently, in CR energy, biomass utilization ranges from $1,5 \%$ to $2 \%$ of the total primary resources. However, the target for the year of 2010 is to ensure that $8 \%$ of power and $6 \%$ of heat energy come from renewable sources. Table 2 shows an overview of biomass to ensure such targets [3].

Table 2: $\quad$ Energy production from biomass in 2010.

\begin{tabular}{|l|c|c|c|c|}
\hline \multicolumn{1}{|c|}{ Biomass type } & $\begin{array}{c}\text { Energy } \\
(\mathbf{\%})\end{array}$ & $\begin{array}{c}\text { Total } \\
(\mathbf{P J})\end{array}$ & $\begin{array}{c}\text { Out of this } \\
\text { heat }(\mathbf{P J})\end{array}$ & $\begin{array}{c}\text { Power } \\
(\mathbf{G W h})\end{array}$ \\
\hline Wood and wood waste & 24 & 33,1 & 25,2 & 427 \\
\hline Grain and oil plant straw & 11,7 & 15,7 & 11,9 & 224 \\
\hline Energy crops & 47,1 & 63 & 47,7 & 945 \\
\hline Biogas & 16,3 & 21,8 & 15,6 & 535 \\
\hline Total & $\mathbf{1 0 0}$ & $\mathbf{1 3 3 , 6}$ & $\mathbf{1 0 0 , 4}$ & $\mathbf{2 2 3 1}$ \\
\hline
\end{tabular}

\subsection{Combustible waste for energy purposes}

Recently there have been increasing efforts to increase energy production from renewable resources. Approved state power industry conception assumes an increase of a portion of renewable resources for the production of electrical energy by the year 2010, up to a total of $8 \%$. In the Czech Republic the energy 
from renewable resources accounts for approximately $2.3 \%$ of the present consumption of primary energy resources. The largest contribution to power from renewable resources of energy (RRE) has solid biomass (74\%) followed by water power $(12 \%)$ and biologically decomposable portion of incinerated waste $(5 \%)$. Liquid bio-fuels reach over $6 \%$ of total power production from RRE [5]. Usage of biogas for power production is about $3 \%$ and wind energy usage is so far totally negligible. From this proportion, it is clear that the biomass will be the principal article used to achieve the binding goals in 2010 . It would be wrong not to take into account another class of potential power resources, i.e. waste. These are the substances that are not recyclable under the present available technical possibilities, while keeping balance of environmental, economical and social aspects. Because this waste is useless even as a secondary raw material, it usually ends up on tips, with a negative impact on living environments, even though it has considerable power potential. Such waste substances are however, pre-treated for fuel production, so harmful substances are eliminated and its energy potential may be fully used.

\section{Experimental works}

In terms of the first phase of experimental work a few samples of multicomponent fuel were prepared from the following components; brown coal, waste biomass, waste paper. For the preparation of ecological fuels, the input coal was high-sulphur coal. The coal was sampled in the Komořany preparation plant prior to a production of graded ranks (i.e. nut coal, cobbles) [2]. The first sample was prepared from coal and a high proportion of biomass. The second sample was prepared from coal and scrap paper. The final sample was prepared from coal and a mixture of energy-utilisable wastes, mainly crushed plastic bottles and paper. Table 3 displays a recipe according to which briquette samples have been prepared.

Table 3: $\quad$ Fuel recipes.

\begin{tabular}{|l|c|c|c|}
\hline & \multicolumn{3}{|c|}{ Content of fuel constituents-press mixture (in wt per cent) } \\
\hline Fuel constituent & Sample 1 & Sample 2 & Sample 3 \\
\hline Brown coal & 45,05 & 42,37 & 42,38 \\
\hline Energy sorrel & 45,05 & 0 & 16,95 \\
\hline Dry hydrate & 2,70 & 2,54 & 2,54 \\
\hline Ground scrap paper & 0 & 42,37 & 16,95 \\
\hline Crushed plastics & 0 & 0 & 8,47 \\
\hline
\end{tabular}

The fuel was prepared in the form of briquettes on laboratory press KAHL14-175. The pressing procedure consists of rolling the input material on the matrix by crushing wheels, which causes precompacting, and subsequently the material is pushed into the matrix pressing channels. These channels are shaped so that the pressed material is compacted again and a cylindrical cord of pressed material is pushed out of the matrix [6]. This cord is cut into lengths by means of a cutting machine. 
In terms of the next phase of experimental work, some samples of ecological fuel were prepared from the following components: dusty brown coal, solid product from the pyrolysis of waste rubber; waste fraction from the production of charcoal; products of a wastewater treatment plant. In the accredited test laboratory of VÚHU a.s., a simplified laboratory testing pyrolysis unit was developed with retort made from special material for the thermal processing of brown coal with a weight of approximately $1000 \mathrm{~g}$. The testing unit is equipped with a cooling and separating circuit and a burner for the gas being originated (with properties similar to coal gas).

The temperature program of the laboratory pyrolysis unit (retort) was set to a final temperature of pyrolysis of $750^{\circ} \mathrm{C}$ with a temperature rise and time delay as required, and set temperatures. Figure 1 shows the product of the wastewater treatment plant. Figure 2 shows the ecological fuel produced from this product.

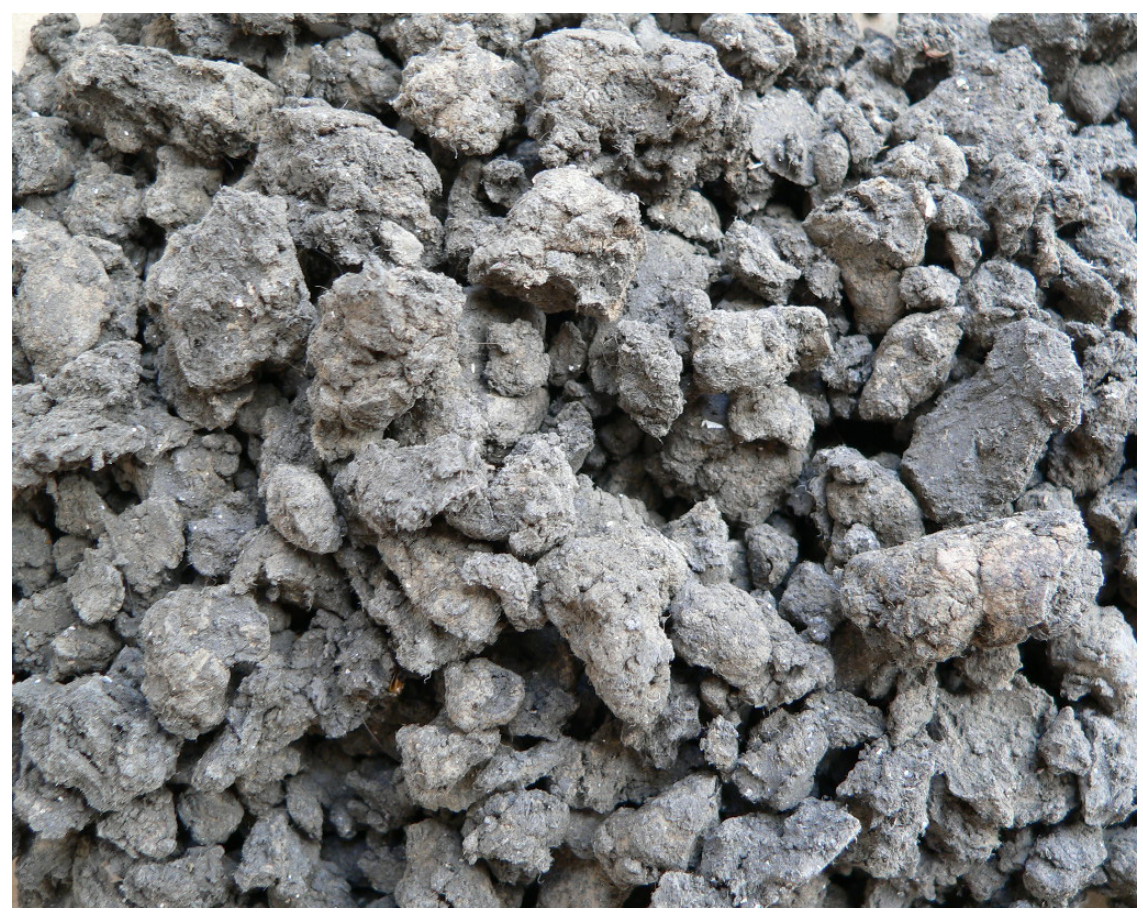

Figure 1: $\quad$ Product of wastewater treatment plant.

\subsection{Combustion tests}

The combustion tests with prepared briquettes were carried out at the Research Power Engineering Centre of the Mining College at the Technical University of Ostrava. Based on the previous experience during combustion tests, a Viadrus Ling 25 boiler was used. During the course of the burning tests, no substantial problem with fuel combustion occurred. In the case of sample 1 combustion, $\mathrm{SO}_{2}$ 
emissions reached approximately $1,328 \mathrm{mg} \cdot \mathrm{m}^{-3}$, which corresponds to a desulphurization of $62,4 \%$. With this sample, a high concentration of emitted CO was measured, which however, complies with the knowledge of biomass combustion, and of sorrel in particular. In the case of Samples 2 and 3, the levels of desulphurization were $63.5 \%$ and $63.3 \%$ respectively. Figure 3 shows combustion of sample 1 . In Table 4 the results of combustion tests are shown.

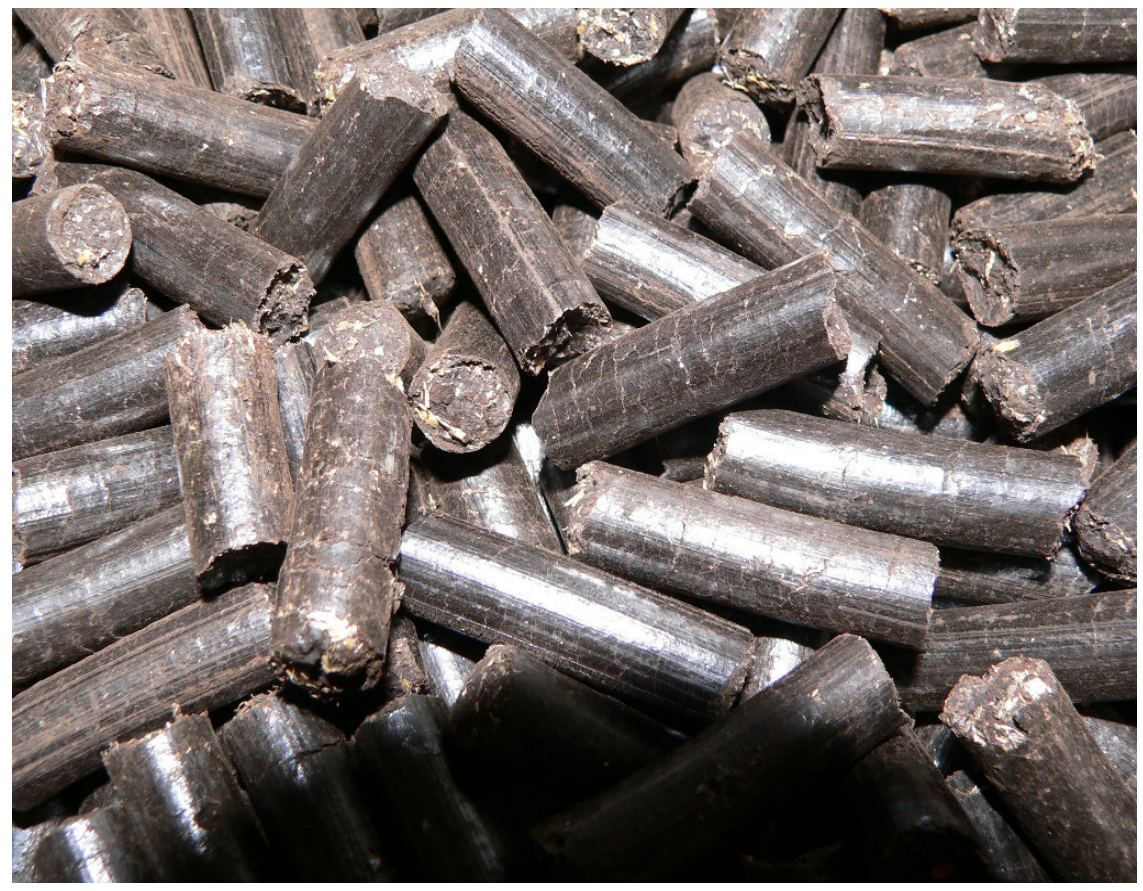

Figure 2: Ecological fuel prepared from the product of wastewater treatment plant from a combination of brown coal and biomass.

\section{Conclusion}

The aim of this project was to verify experimentally and in semi-operation the possibility of using reprocessed waste as components of a new type of fuel for small and middle-size sources including combustion tests with pollution measuring. We can consider the following points as the main benefits of the project:

- Utilisation of fine fractions, impossible to sell, produced by treatment of quality types of brown coal

- Utilisation of brown coal with high sulphur content for production of ecological fuel using biomass and additives 
- Utilisation of selected types of burnable waste as another component of ecological fuel based on brown coal with a high sulphur content

- Utilisation of renewable energy sources based on biomass

- Burning of new types of products in existing modern types of combustion boilers without having to undertake any constructional modifications.

Based on the results, it is possible to say that such ecological fuel can be used as a substitute for burning pure brown coal with a higher sulphur content.

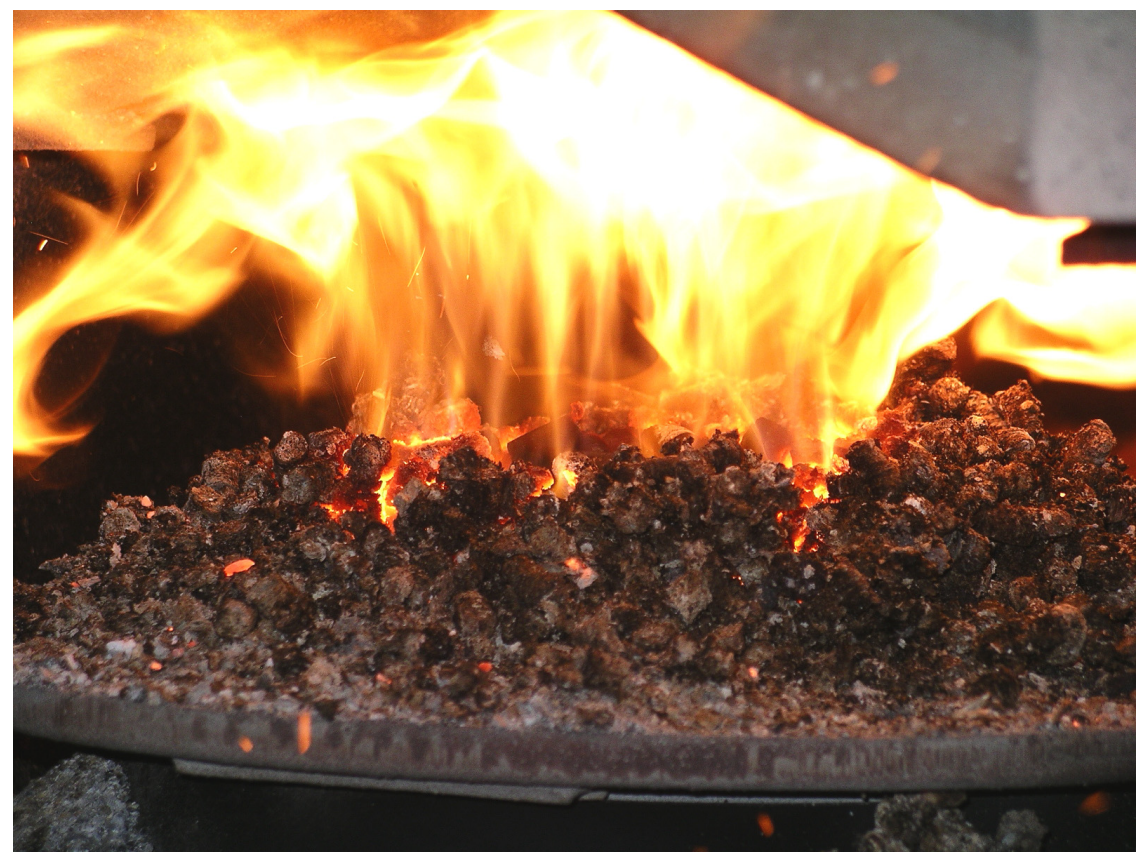

Figure 3: $\quad$ Combustion of sample 1.

Table 4: Results of combustion tests.

\begin{tabular}{|c|c|c|c|c|c|}
\hline Fuel & $\begin{array}{c}\mathrm{CO} \\
{\left[\mathrm{mg} \cdot \mathrm{m}^{-3}\right]}\end{array}$ & $\begin{array}{c}\mathrm{CO}_{2} \\
{\left[\mathrm{~g} \cdot \mathrm{m}^{-3} \mathrm{n}\right]}\end{array}$ & $\begin{array}{c}\mathrm{SO}_{2} \\
{\left[\mathrm{mg} \cdot \mathrm{m}^{-3} \mathrm{n}\right]}\end{array}$ & $\begin{array}{c}\mathrm{NO}_{\mathrm{x}} \\
{\left[\mathrm{mg} \cdot \mathrm{m}^{-3}\right]}\end{array}$ & $\begin{array}{c}\text { Efficiency of } \\
\text { desulphurization } \\
{[\%]}\end{array}$ \\
\hline $\begin{array}{c}\text { Brown } \\
\text { coal }\end{array}$ & $\mathbf{1 ~ 1 8 6}$ & $\mathbf{2 5 1}$ & $\mathbf{3 5 3 1}$ & $\mathbf{4 3 2}$ & - \\
\hline Sample 1 & 5318 & 263 & 1328 & 313 & 62,4 \\
\hline Sample 2 & 1356 & 270 & 1290 & 351 & 63,5 \\
\hline Sample 3 & 1885 & 269 & 1294 & 386 & 63,3 \\
\hline
\end{tabular}




\section{Acknowledgements}

This work has been created in terms of the research intention MSM 4456918101 "Research of physico-chemical properties of materials involved in mining and utilisation of coal and their influence on the environment in the region of northwest Bohemia" with the assistance and contribution of the Ministry of Education, Youth and Physical Training of the Czech Republic.

\section{References}

[1] Sedláček, P., Maček, S., Šafářová, M., Kusý, J.: Využití pyrolýzy odpadů pro zvýšení užitných vlastností paliv ČR, Sborník Mezinárodní konference Recyklace odpadů VIII, s. 345-350, ISBN 80-248-0560-X (Using waste pyrolysis for increasing fuel qualities in the Czech Rep., Collection of International Waste Recycling Conference VIII)

[2] Sedláček, P., Valeš, J., Fečko, P., Čablík, V.: Výroba směsných pelet z hnědého uhlí a biomasy, Publikace: Zpravodaj Hnědé uhlí 4/2003, s.510, ISSN 1213-1660 (Production of mixed briquettes from brown coal and biomass)

[3] Obnovitelné zdroje energie v roce 2003, Stručný přehled zpracování výkazu ENG (MPO) 4-01), MPO 2004 (Renewable Energy Sources- Brief overview)

[4] Roubíček, V., Buchtele, J.: Uhlí - zdroje, procesy, užití, Ostrava 2002, Sborník. 6th Conference on Environment and Mineral Processing, part II,s.797-802, ISBN 80-248-0072-1 (Coal-sources, Processes, Utilisation, Ostrava 2002, Collection)

[5] Nováček, J.: Technologie úpravy uhlí II, VŠB TU Ostrava, (Coal Processing Technology)

[6] Švehla, E, Bernáth, V.: Úpravnické stroje a zařízení, SNTL 1964 (Treatment Machines and Equipment) 